\title{
Charnley 式股関節全置換術の術後脱臼について
}

\author{
長崎大学医療技術短期大学部 \\ 池田定 倫 \\ 長崎大学医学部整形外科 \\ 岩 崎 勝 郎
}

\author{
Dislocation of Charnley Low-Friction Arthroplasty \\ by \\ Sadamichi Ikeda \\ School of Allied Medical Sciences, \\ Nagasaki University \\ Katuro Iwasaki \\ Department of Orthopaedic Surgery, \\ Nagasaki University School of Medicine
}

A special review, with the aim of identifying the incidence and the factors of the dislocation of Charnley low-friction arthroplasty, was undertaken. From 1971 to 1986,304 arthroplasties have been performed at Nagasaki University and followed over 2 years.

Dislocation is defined as displacement of the head of the femoral prosthesis out of the prosthetic socket on radiography except the dislocation owing to the loosening of the socket or stem.

Dislocation occurred in 8 of 304 hips (2.6\%): 2 occurred during 3 weeks, 1 at 3 months, and 5 from 4 months to 180 months. Two of these were traumatic dislocations.

In 5 hips, there were inadequate deepening and placement of the acetabular component at operation. In 3 hips, there were varus position of the femoral component, but those varus angles were below 5 degrees. In one hip, there was loss of neck length due to resorption of the femoral calcar. Two dislocations were related to muscle atrophy due to prolonged bedrest and other 2 dislocations were related to scarring from severe trauma or previous surgery.

Only one patient showed complete bony union of the trochanteric osteotomy in dislocated cases, whereas 5 of 7 patients showed complete detachment of trochanter.

Factors contributing to dislocation were inadequate orientations of prosthetic socket and loss of normal tissue tension as a result of muscle atrophy and defective bony union of trochanteric osteotomy.

Charnley 式股関節全置換術(以下, Charnley THR)

は，骨頭径が $22 \mathrm{~mm}$ と小さい事や，外側アプローチを用 いる事そして大転子のトラブルなどの為, 術後脱臼が 多いと考えられている．そこで，今回はこの術後合併 症の発生頻度と時期そして原因について調査したので 報告する。

\section{対象及び方法}

対象は，1971年から1986年までの16年間に長崎大学
で行った Charnley THR で2 年以上経過観察のでき た254例（両側50例）304股である.

このなかで，X線にて骨頭が完全にソケットより 脱転していると確認できた症例を脱臼例とした。但 し, ソケットやステムのルースニングによる脱臼は除 外した．方法は，この脱臼例につきX線よりソケット やステムの設置位置や挿入角度を計測すると共に, 大転子の状態や兜柱変形, 脱臼発生肢位につき調査 した. 
結

果

術後脱臼は女性 6 例，男性 2 例の合計 8 股 $(2.6 \%)$ で, 脱臼の方向は全例が後方脱臼であった．初回脱臼 発生時期を術後 3 週以内を Immediate, 4 週から 3 ケ 月以内を Early，4 ケ月以降を Late と ${ }^{6)} す る と ，$ Immediate 2 例, Early 1 例, Late 5 例で術後 10 年 以上経過して脱臼した症例も 2 例あった. 脱臼回数は 1 回のみに留まっているのは 3 例で他の 5 例は 2 回以 上脱臼をくりかえしていた，原疾患は，変形性股関節 症 5 例であるが，高位脱臼例は含まれていない. 症例 4 は中心性脱臼で寛骨臼の内側下方に骨欠損があった. 症例 6 は大腿骨頚部内側骨折に人工骨頭置換術を行っ た後の中心性陥入に対する再手術例であった。症例 7 は寝たきりの状態の RA であった．脱臼に対する治療 法は，症例 4 のみに観血整復が必要であった。この症 例はこの後大転子部の感染をおこし，締結ワイヤーの 抜去と大転子の切除を受けた。（表 1 )

脱臼発生時の状況や肢位では，歩行時の転倒の 1 例 とベットでの坐位よりすべり落ちた 1 例を除き他の 6 例はベットや畳上での坐位でさらに屈曲, 内転を行っ た時に脱臼が発生していた．脱臼前の ROM では屈曲 $90^{\circ}$ 以上は 3 例でいずれも Late Dislocation の症例 であった.
臼蓋側のX線評価では, ソケット傾斜角を Salvati の分類 ${ }^{5)}$ に従って分けると, Vertical が 1 例で他の 7 例はすべて Neutral であり，その平均角度は $43.8^{\circ}$ で あった.ソケットのはみ出しは 2 例でいずれも臼蓋の リーミングが不足していた.ソケットの高さでは 2 例 で高位に設置されていたが，他の6例はいずれも原臼 にあった.ソケットの摩耗は術後 10 年以上経過の 2 例

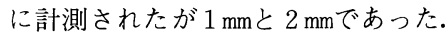

大腿骨側のX線評価では，ステムの位置で 3 例内反 位をとっていたが，その角度はいずれも $5^{\circ}$ 以内であっ た. 頝部長の短縮を示す Distal Migration は 1 例に みられたのみであった。大転子鋼線の折損は 6 例にあ り，4例では Transverse, Vertical の 2 本共に切れ ていた. 大転子の癒合不全が 5 例（1例は感染の為大 転子切除）にあり，そのため大転子の上方転位が 4 例 にみられた。

以上の結果に, 脩柱変形と日常生活能力を加えて脱 臼を発生させたと考えられる因子をまとめると，ソケッ トの設置角度や位置の異常が 5 例，ステムの位置の異 常が 3 例, Distal Migration による䅡部長の短縮が 1 例，大転子の癒合不全による上方転位が 4 例，大転 子切除 1 例, Salvage 手術と外傷による瘢痕が著明で あったもの 2 例, 背柱変形が 2 例, 長期臥床や筋力低 下がひどいもの 2 例, 脱臼時かなりの外力が加わった

表 1. 脱 $⿴ \zh11$ 症例

\begin{tabular}{|c|c|c|c|c|c|c|c|}
\hline $\begin{array}{l}\text { 症例 } \\
\text { 番号 }\end{array}$ & 名 前 & $\begin{array}{l}\text { 手術時 } \\
\text { 年 粭 }\end{array}$ & 性 & $\begin{array}{c}\text { 脱臼発生時期 } \\
\text { (術後) }\end{array}$ & $\begin{array}{l}\text { 脱臼 } \\
\text { 回数 }\end{array}$ & 原疾患 & $\begin{array}{l}\text { 脱 臼 } \\
\text { 治療法 }\end{array}$ \\
\hline 1. & H. O & 58 & $\mathrm{~F}$ & 133ケ月 & 3 & $\begin{array}{l}1 \text { 次性 } \\
\text { O. A }\end{array}$ & 徒手整復 \\
\hline 2. & M. $\mathrm{H}$ & 74 & $\mathrm{~F}$ & 13ケ月 & 2 & $\begin{array}{l}2 \text { 次性 } \\
0 . \mathrm{A}\end{array}$ & " \\
\hline 3. & M. T & 70 & $\mathrm{~F}$ & 3 週 & 1 & $\begin{array}{l}1 \text { 次性 } \\
\text { O. A }\end{array}$ & " \\
\hline 4. & M. $\mathrm{K}$ & 76 & M & 2 週 & 4 & $\begin{array}{l}\text { 脱臼 } \\
\text { 骨折 }\end{array}$ & 観血整復 \\
\hline 5. & A. $U$ & 50 & $\mathrm{~F}$ & 180ケ月 & 1 & $\begin{array}{l}1 \text { 次性 } \\
\text { O. A }\end{array}$ & 徒手整復 \\
\hline $6 .^{*}$ & M. T & 76 & $\mathrm{~F}$ & 14ケ月 & 1 & $\begin{array}{l}\text { 内側 } \\
\text { 骨折 }\end{array}$ & " \\
\hline 7. & J. T & 74 & M & 4 週 & 2 & R. A & " \\
\hline 8. & T. $\mathrm{K}$ & 52 & $\mathrm{~F}$ & 6ケ月 & 2 & $\begin{array}{l}2 \text { 次性 } \\
\text { O. A }\end{array}$ & $"$ \\
\hline
\end{tabular}

*人工骨頭置換術 
もの 2 例であった.これらの因子は，単独では原因と なっているのでなくいくつかの因子が組み合わさって 脱臼を発生させているが，特にソケットの設置異常に 大転子の上方転位が加わると脱臼の危険は大きいと考 えられ，とりわけ，大転子の上方転位と外転筋の機能 低下は最も大きい脱臼危険因子と考えられた.

\section{考察}

術後脱臼の発生頻度は, Mckee-Farrar や Müller では $2 \sim 3 \%$, Ring で0.3\%, Trapezoidal で1.1\% そして, Charnley 式では, Bergstrom ${ }^{1)}$ の 4.6\%が最 高で, Charnley の最近の報告 ${ }^{3)}$ ではいずれも $1 \%$ 以下 である. 今回の調査では外傷性脱臼の 2 例を含め 8 例 (2.6\%) と高頻度であった.

股関節全置換術の術後脱臼の原因となる因子として は，ソケットやステムのデザインや余分なセメントや 骨棘の取りのこしなどの Mechanical Factor，あるい はソケットの位置や高さ, 頚部長そして股関節周囲組 織の弾力性などの Anatomical Factor, さらにステム の設置, 大転子の固定そして術後の看護とリハビリテー ションなどの Technical Factor があげられる.

Eftekhar ${ }^{4)}$ は，骨頭径と脱臼の頻度には関係はな く, 脱臼の原因は頚部長の短縮や股関節周囲組織の挫滅
による安定性の欠如であると述べ, stable な Charnley THR の Traumatic Dislocation の頻度は正常股関節 と変わらないとしている.

今回の調査でソケットの設置角度や位置の異常があっ たのは 5 例であるが中心性脱臼骨折の 1 例を除きいず れも. Late Dislocation で, かつ全脱臼症例の平均設 置角度は $43.8^{\circ}$ と Neutral であった. ステムの位置の 異常は 3 例にあったが, すべて 5 以内人わずかであっ た.また，ソケットやステムの設置異常のみの因子で 脱臼を発生している症例はなかった。

今回の術後脱臼例の調査で最も特徴的だったのは, 大転子の癒合不全と長期臥床に伴う外転筋力の低下が 考えられる症例が多かったことである．大転子の骨癒 合が完成していたのは 1 例のみで， 4 例に大転子の上 方転位がみられたことであった。これは転倒が原因の 1 例（症例 1 ）と Immediate 例（症例 3 ）の 2 例を除 $<5$ 例中 4 例（症例 $2,5,6,7$ ）であり残りの 1 例 (症例 8 ) は乳ガンと腎機能障害そして術後の腓骨神 経麻痺のため筋力が低下していた症例であった。また もう 1 例の Immediate 例 (症例 4 ) は初回脱臼時の観 血整復後に大転子部の感染を引き起こしワイヤーの抜 去と大転子の切除を受けていた。（表 2)

この様に, 術後早期の為まだ十分股関節周囲筋の筋

表 2. Contributing Factors to Dislocation

\begin{tabular}{|c|c|c|c|c|c|c|c|c|c|}
\hline $\begin{array}{c}\text { Case } \\
\text { No. }\end{array}$ & $\begin{array}{l}\text { Position of } \\
\text { Cup }\end{array}$ & $\begin{array}{l}\text { Position of } \\
\text { Stem }\end{array}$ & $\begin{array}{c}\text { Loss of Neck } \\
\text { Length }\end{array}$ & $\begin{array}{c}\text { Trochanter } \\
\text { Nonunion }\end{array}$ & $\begin{array}{c}\text { Pre. Surgery, } \\
\text { sev. Trauma }\end{array}$ & $\begin{array}{l}\text { Postural } \\
\text { Deformity }\end{array}$ & $\begin{array}{l}\text { Systemic } \\
\text { Disorders }\end{array}$ & $\begin{array}{c}\text { Traumatic } \\
\text { Dislocation }\end{array}$ & $\begin{array}{l}\text { Onset of } \\
\text { dislocation }\end{array}$ \\
\hline 1. & $\begin{array}{c}(+) \\
\text { Vertical }\end{array}$ & $\begin{array}{c}(+) \\
3^{\circ} \text { Varus }\end{array}$ & $(-)$ & $(-)$ & $(-)$ & $(+)$ & $(-)$ & $(+)$ & Late \\
\hline 2. & $\begin{array}{c}\text { High } \\
\text { Position }\end{array}$ & $(-)$ & $(-)$ & $(+)$ & $(-)$ & $(+)$ & $(-)$ & $(+)$ & Late \\
\hline 3. & $(-)$ & $(-)$ & $(-)$ & $\begin{array}{l}\text { fibrous } \\
\text { union }\end{array}$ & $(-)$ & $(-)$ & $(-)$ & $(-)$ & Immediate \\
\hline $4 .^{*}$ & $\begin{array}{c}\text { Insufficient } \\
\text { coverage }\end{array}$ & $\begin{array}{c}(+) \\
3^{\circ} \text { Varus }\end{array}$ & $(-)$ & $(+)^{* *}$ & $(+)$ & $(-)$ & $(-)$ & $(-)$ & Immediate \\
\hline 5. & $\begin{array}{c}\text { Insufficient } \\
\text { coverage }\end{array}$ & $\begin{array}{c}(+) \\
4^{\circ} \text { Varus }\end{array}$ & $(+)$ & $(+)$ & $(-)$ & $(-)$ & $(-)$ & $(-)$ & Late \\
\hline 6. & $(-)$ & $(-)$ & $(-)$ & $(+)$ & $(+)$ & $(-)$ & $(-)$ & $(-)$ & Late \\
\hline 7. & $(-)$ & $(-)$ & $(-)$ & $(+)$ & $(-)$ & $(-)$ & $(+)$ & $(-)$ & Early \\
\hline 8. & $\begin{array}{l}\text { Insufficient } \\
\text { coverage }\end{array}$ & $(-)$ & $(-)$ & $\begin{array}{c}\text { fibrous } \\
\text { union }\end{array}$ & $(-)$ & $(-)$ & $(+)$ & $(-)$ & Late \\
\hline
\end{tabular}

* Acetabular

Fracture
$* *$ Removal

of wires due to infection 
力が回復していない時期，あるいは全身性疾患により 長期臥床の為筋力低下がある時や，大転子の上方転位 による外転筋の機能不全の存在下で過度の屈曲とそれ に内転が加わる事が術後脱臼の原因と考えられた.

Charnley THR における大転子の骨切りと必要に 応じての外側あるいは下方への移行手技は，正確に ソケットとステムを設置し，かつ股関節の安定性を得 る為には必須の手技であるとされている.しかし， Thompson $^{7)}$ は，大転子の骨切りを行った症例と行わ なかった症例の予後調査の結果, 通常の症例では大転 子の骨切りは必要ではなく, その適応は人工骨頭後や 移動骨切り術後の Salvage 手術, $30^{\circ}$ 以上の屈曲拘 縮, $10^{\circ}$ 以上の外旋変形例, そして高度な臼蓋形成不全 や Protrusio Acetabuli の症例にあると述べているが, Browne $^{2)}$ は，2.8\%の大転子骨切りに伴うトラブルが あったにも関わらず，このアプローチは正確な手術と より良い外転機構を得る為また骨幹部骨折の危険を最 小にするには必要であると述べている，私たちもこの 意見に賛成であり今後ともCharnley の原法に従い THR を行っていきたい.しかし，大転子の上方転位 は術後脱臼の最大の原因であることから，今一度，大 転子骨切り部の確認と再接合の手技については考虑し なければならない。

\section{ま と め}

1971年から1986年の16年間に行った Charnley THR 304股につき術後脱臼の発生頻度やその原因につき調査 した。その結果，術後脱臼は 8 股 $(2.6 \%)$ で，術後 10 年以上経過しても 2 例に脱臼が発生していた.

脱臼の原因は単独ではないが，その中でもソケット の設置異常に股関節周囲組織の緊張の低下が加わった 事が原因と考えられた。とりわけ，大転子の上方転位 や長期間臥床による外転筋力の低下は過度の屈曲, 内 転位の際の脱臼誘発力をブロック出来ないのではな
いかと考えられた。

\section{参考 文 献}

1) Bergstrom E.A. et al: Complication after total hip arthroplasty according to Charnley in a Swedish series of cases. Clin. Orthop. 95: 91-97, 1973.

2) Browne A.O. et al: Trochanteric osteotomy in Charnley low-friction arthroplasty of the hip. Clin. Orthop. 211: 128-133, 1986.

3) Charnley J. et al : Etiology and incidence of dislocation in Charnley low-friction arthroplasty. Internal Publication No.46, Center for Hip Surgery, Wrightington Hospital, England, 1974.

4) Eftekhar N.S. et al: Experience with low-friction arthroplasty. Clin. Orthop. 95:60-68, 1973.

5) Salvati E.A. et al : Radiology of total hip replacements. Clin. Orthop. 121:74-82, 1976.

6) Stinchfield F.E.: Priciples of total hip arthroplasty. Eftekhar, Saint Louis, 1978.

7) Thompson R.C. Jr.et al : The role of trochanteric osteotomy in total hip replacement. Clin. Orthop. $106: 102-106,1975$.

質 問留米大学 井上 明生 術後脱臼の原因として，大転子癒合不全をあげてお られますが, 大転子癒合不全がどれくらいの率で発生 して，そのうちのどれだけに脱臼がみられたのですか.

解 答 長崎大学 池田 定倫

1 ）今回の全症例の大転子のトラブルについては, 調査していません。文献上では, 約 $3 \%$ 内外との報告 です.

2) 大転子の上方転位のみによる問題であれば，大 転子の下方移行で再脱臼は防止できますが，その他の 要因, 特に大腿筋膜張筋の弱化等の股関節全体の弱化 の例には, 術後 $3 \sim 4$ 週の外転枕の使用などの配慮が 必要です。大転子の骨切りは, Charnley 手術では, 必須の手技と考えており，今後も継続して行います。 